\title{
Rural Women Who Undertake and Empower Themselves: Comparative Analysis in Communities in Mexico
}

\author{
Héctor Manuel Villanueva Lendechy ${ }^{1}$, Ivonne Tapia Villagómez ${ }^{2}$ \\ ${ }^{1,2}$ Universidad Iberoamericana Puebla, México \\ hector.villanueva@iberopuebla.mx
}

\begin{abstract}
This research presented a comparative analysis of 4 original and qualitative studies that were carried out in 2018 and 2019, in the Mexican companies Taselotzin, Artemali and in El PIRA Hermanos, located in the state of Puebal and a women's venture in the community of Samaria in the state of Veracruz. In these investigations, the relationship between the variables was identified: social entrepreneurship and empowerment of rural women. The method used in the investigations was inductive and the techniques were documentary and panel interview in situ, the categories of analysis of the previous research: self-own business, decision making for the community, training, learning, culture and sustainability. It was concluded that the 4 ventures are prone to training, which contributed to organizational learning and innovation, and in turn, to make the Company more competitive. In addition, Taselotzin opposed the construction of the High Voltage line in Cuetzalan, Artemali participated in health campaigns, moderately collects its raw material and takes care of the forest from the depredation of its resources. The PIRA Brothers regulate the activity of pyrotechnics at the state level to avoid accidents that become tatal and the farmers of Samaria pratice organic agricultura.
\end{abstract}

Keywords: Social entrepreneurship; women's empowerment; training; learning; sustainability.

\section{Introduction}

Neoliberal capitalism is characterized by capital accumulation, exacerbated competitiveness, hyper consumption, hyper individualism and the depredation of natural resources by putting efficiency and productivity before decernt work. Some of the consequences of centuries of capitalism are the lacerating inequality in income distribution and global climate change that will cause life on Earth to be greatly affected, even difficult to inhabit.

The United Nations Organization (ONU) carries out some actions to counteract the negative consequences of capitalism, for example, designed and is implementing an agenda with 18 objectives for sustainable development, so that countries that contribute to this plan must commit to eradicate hunger eliminate poverty, reduce inequalities, promote clean energy, decent work, implement concrete actions to mitigate climate change, promote responsible consumption, among others.

In this order of ideas, governments have the titanic challenge of generating a more sustainable and inclusive development, through public policies that promote corporate social responsibility and generate social enterprises that privilege the moderate use of natural resources, the use of energy clean, the eradication of man and poverty, formal quality education, a public health system with more quality and sustainable development, among others.

Mexico is a country of notable inequalities, poverty and contrasts, only a very small number of powerful families that hace much of fhe conuntry's wealth. This hierarchical capitalism is of Little interest in implementing and measuring its sustainability strategies and, if it has a social responsibility program, it generally obeys a fiscal strategy to not pay taxes via 
donations to organizations, as a result, the social impact as fade because they respond to the cost-benefit criteria.

Therefore, the Alliance between government, companies, universities and civil society is necessary to promote the creation of companies that act in a sustainable way inside and outside them. These companies could balance the balance with companies that do not have a sustainability strategy and reverse the bleak environmental landscape presented in the ONU report presented in Nairoby, Kenya, which, life on Earth as we know it has as a term the year of 2030.

Universities must solve the problems of their environment with a global vision but acting locally, for example, through research. For this reason, in the Business Department of the Universidad Iberoamericana Puebla, there is a qualitative research Project of social entrepreneurship and the empowerment of rural women. The companies that were studied in 2018 and 2019 were entrepreneurship in the community of Samaria, municipality of Catemaco, in the state of Veracruz, the companies: Hotel Taselotzin, Artemali and El PIRA Hermanos, in state of Puebla. All companies are run by rural women. Base on the above, the following question is posed.

Compare the social enterprises of Samaria, Taselotzin, Artemali and EL PIRA Hermanos through the categories of analysis: self-own business, sustainability, learning, community decision making, training and culture.

\section{Review of Literature}

\subsection{Social entrepreneurship}

Social enterprises are productive structures that have an imprint of social benefit and, in this sense, it can be affirmed that they are alternative forms of companies within a neoliberal capitalism, which houses organizations oriented to profit, capital accumulation and enrichment of few people, contributing to the polarization between the city and the countryside. On the contrary, in social enterprises, cooperative work and decision-making are promoted in a consensual or democratic way: the partners are simultaneously the workers as they determine how and in what way the benefits will be applied and the benefits will be distributed. In addition, they use management techniques that contribute to the sustainability and sustainability of the Company. The characteristics of social entrepreneurship, after having reviewed some authors (Palacios, 2010; Kliksberg 2011; Alonso, González y Nieto, 2015; Rodríguez y Flores, 2016, Guzmán y Trujillo, 2008) are the following: 1. The embryonic germ of social good; 2. A sustainable social change, which implies: a) The sustainability of the organization (financial Independence and profitability) and b) The achievement of social change on an ongoing basis; 3 . The improvement of the conditions of at least one group; 4 . The use of management methods and techniques; 5 . The possibility of new companies eliminating codependence.

Social entrepreneurship unlike traditional entrepreneurship, does not favor the generation of income and profits, if not the social problem to be solved. The methodology to solve it is: identify the causes, investigate what was done to solve it, state the research question and find a viable solution in the social and economic, for which, there are several social business models that can be used (for example, business systems "B"). 


\subsection{The empowerment of women}

The neoliberal, hegemonic and patriarchal capitalist system inherited this characteristic from the Company, hence there is no gender equality in working conditions. The inequality of conditions in which women live is structural and systemic, which slows their personal and professional aspirations. However, for decades a process of empowerment of women was created, legitimized and promoted by the governments of several countries and international institutions such as the ONU.

The use of the Word female empowerment has its roots in European feminist movements and in the United States of America. In Latin America, the feminist movement emerged at the end of the 19th century, in South America and is currently struggling to deconstruct a Eurocentric, colonial patriarchal and Catholic heritage, which generated genocide, slavery and a lacerating sexual violence in the natives, mainly towards women. The current challenge of the Latin American feminist movement is to adapt to modernity but incorporate knowledge of native cultures (Bard, 2017).

The use of the term female empowerment in Latin America, in its origin, were not related to companies, note even to traditional companies; rather, it was based on movements of social change that sought the equality of women's rights and of the man, for example, the right to a formal academic education and the right to vote, among others. Subsequently, he ventured into the business field, in which women fight for equal rights to men, for example, equal rights to occupy executive positions and to pay an equal salary and benefits when the occupy equal positions.

The empowerment of women generally requires support and solidarity among them because the association and collective action of women is a strategy to understand and uproot the idea that male domination is inevitable and irreversible and, therefore, to break the chains of subordination of women to men. This process was accompanied by training in gender issues and reproductive education, it is not linear and the important thing is the continuity and commitment of the grouped women. However, some feminist movements are also supported by men, who understand that change needs both genders to complement and unite.

The process of female empowerment has three dimensions; personal, collective and close relationships. Some of the collective actions influence the transformation of structures and institutions that support gender discrimination. In any of the dimensions, the purpose is to build a broad and strong social capital, based on trust, which allows specific objectives related to the improvement of the living conditions of the women that make up the social network. In Mexico, since 1960 an irreversible process of changes in gender roles began, which has contribute to female empowerment. For example, in rural areas, women, often indigenous, became heads of households, because of their partner's migration to another country or another state, in the search for better living conditions, due to the death of this one or by its absence. The aforementioned, forced her to use the resources available to her and dedicate herself to agriculture to generate monetary resources and cover her family's needs. This phenomenon was called the feminization of the countryside or agriculture (CEDRSSA, 2014; Garay, 2015; López Guerra, et al, 2017).

In this sense, there are more women who start their self-own business with available agricultural resources or that are granted through remittances, thus initiating a process of personal, economic and political-social empowerment (Vázquez, Mortera, Rodríguez, Martínez y Velázquez, 2013; Soler, et al 2014). Most of these women do not have the administrative training to start and mange a business. Nor do they know about techniques for 
sowing and harvesting, which causes their businesses to fail, therefore, NGOs, universities and the government must support these ventures.

However, the empowerment of rural women is not only related to business entrepreneurship in the agricultural field (agriculture, livestock and related), it is also observed that empowerment is related to the entrepreneurship of other types of businesses that allow it to generate income for your family, either because you are the only person who contributes, because you are the one who contributes the most or because it complements the income of another family member, whether your partner or not.

The empowerment of rural women is related to variables such as academic degree, business investment, participation in commerce, high level of willingness to work in the community, satisfaction in paid work, among others (Vázquez et al, 2013). In the same order of ideas, the categories of female rural empowerment are considered to be: self-own business, own business decision making, community decision making and training.

However, rural women entrepreneurs have not left behind the roles they traditionally played and must fulfill them in parallel, that is, they educate their children, perform domestic activities and attend to their partner, so the woman performs a double workday and triple, generating a great emotional, physical and mental fatigue. So the entrepreneurial spirit of women must overcome many obstacles so that their Company can be maintained and profitable.

\section{Methodology}

The research used the comparative method for qualitative and original research carried out in the states of Puebla and Veracruz, in Mexico, in 2018 in the community of Samaria, municipality of Catemaco, Veracruz and in 2018 at the Taselotzin hotel, in Cuetzalan, Puebla, as well as in 2019, in the El PIRA Hermanos companies, located San Miguel Zacaola and in Artemali, located in Tepatlaxco de Hidalgo, both in the state of Puebla. The categories of analysis that were compared were: self-own business, decision making for the community, training, sustainability, learning and culture. These categories of analysis conform, in part, to the variable called rural women's empowerment, the other variable is social entrepreneurship. The 4 original investigations used the inductive method, the documentary technique and the on-site panel interview. First, the results regarding these categories will be shown in a very summarized way in a comparative table and from there the conclusions will be analyzed and generated.

\section{Discussion}

The following comparative table summarizes the results of the 6 analysis categories in the community of Samaria, Artemali Company, Taselotzin Company and EL PIRA Hermanos Company.

Table. Comparison of the analysis categories: self-own business, decision making for the community, training, learning, culture and sustainability.

\begin{tabular}{|c|c|c|c|c|}
\hline Category & Taselotzin & Artemali & $\begin{array}{c}\text { El PIRA } \\
\text { Hermanos }\end{array}$ & $\begin{array}{c}\text { Community of } \\
\text { Samaria }\end{array}$ \\
\hline
\end{tabular}




\begin{tabular}{|c|c|c|c|c|}
\hline $\begin{array}{l}\text { Self-own } \\
\text { business }\end{array}$ & $\begin{array}{l}\text { It was } \\
\text { undertaken after } \\
\text { the heavy rains } \\
\text { in the city } \\
\text { Cuetzalan, } \\
\text { devastated the } \\
\text { cultivation of } \\
\text { pepper and } \\
\text { coffee. The } \\
\text { women made } \\
\text { handicrafts and } \\
\text { joined the } \\
\text { Tosepan } \\
\text { cooperative, but } \\
\text { then decided to } \\
\text { retire because } \\
\text { there was no } \\
\text { gender equity in } \\
\text { the decision- } \\
\text { making process } \\
\text { to market their } \\
\text { handicrafts. }\end{array}$ & $\begin{array}{l}\text { The business } \\
\text { started after } \\
\text { being invited to } \\
\text { a handicraft fair } \\
\text { and receiving a } \\
\text { training course } \\
\text { for women from } \\
\text { the city of } \\
\text { Tlapa, Guerrero, } \\
\text { Mexico, who } \\
\text { developed and } \\
\text { sold ocoxal } \\
\text { crafts. }\end{array}$ & $\begin{array}{l}\text { Before the } \\
\text { pyrotechnics } \\
\text { the owner } \\
\text { undertook } \\
\text { other } \\
\text { businesses } \\
\text { without } \\
\text { success, } \\
\text { therefore, } \\
\text { decides to } \\
\text { venture into the } \\
\text { pyrotechnics, } \\
\text { business that } \\
\text { her late } \\
\text { husband } \\
\text { practiced. }\end{array}$ & $\begin{array}{l}\text { The women of } \\
\text { the community } \\
\text { undertook to } \\
\text { improve family } \\
\text { economic } \\
\text { conditions and } \\
\text { were promoted } \\
\text { by a civil } \\
\text { association. } \\
\text { Entrepreneurship } \\
\text { aims at food } \\
\text { self-sufficiency. }\end{array}$ \\
\hline Training & $\begin{array}{l}\text { They were } \\
\text { trained in } \\
\text { business } \\
\text { administration, } \\
\text { brand } \\
\text { registration, } \\
\text { embroidery } \\
\text { design, shirt } \\
\text { making and } \\
\text { sewing, product } \\
\text { marketing, "M" } \\
\text { certification and } \\
\text { women's rights. }\end{array}$ & $\begin{array}{l}\text { They were } \\
\text { trained by } \\
\text { artisans from the } \\
\text { city of Tlapa, } \\
\text { Guerrero and } \\
\text { artisans from the } \\
\text { state of } \\
\text { Michoacán and } \\
\text { the state of } \\
\text { Mexico. They } \\
\text { also received } \\
\text { courses on the } \\
\text { subjects: } \\
\text { pricing, } \\
\text { calculation of } \\
\text { production } \\
\text { costs, } \\
\text { improvement of } \\
\text { self-esteem and } \\
\text { empowerment } \\
\text { of women. }\end{array}$ & $\begin{array}{l}\text { They were } \\
\text { trained in } \\
\text { techniques and } \\
\text { administrative } \\
\text { tools, design } \\
\text { and } \\
\text { implementation } \\
\text { of pyromusical } \\
\text { and } \\
\text { pyrotechnic } \\
\text { shows, safety } \\
\text { and prevention } \\
\text { of occupational } \\
\text { accidents, } \\
\text { management of } \\
\text { chemical } \\
\text { substances } \\
\text { used in the } \\
\text { manufacture of } \\
\text { pyrotechnic } \\
\text { devices, } \\
\text { warehouse } \\
\text { management }\end{array}$ & $\begin{array}{l}\text { They were } \\
\text { trained in } \\
\text { vegetable } \\
\text { planting, } \\
\text { sustainable land } \\
\text { use, organic } \\
\text { agriculture, and } \\
\text { also in the areas: } \\
\text { women's } \\
\text { empowerment } \\
\text { and women's } \\
\text { sexual and } \\
\text { reproductive } \\
\text { health rights. }\end{array}$ \\
\hline
\end{tabular}




\begin{tabular}{|c|c|c|c|c|}
\hline & & & $\begin{array}{l}\text { and production, } \\
\text { sales, } \\
\text { marketing, } \\
\text { costs, } \\
\text { accounting and } \\
\text { human } \\
\text { resources. }\end{array}$ & \\
\hline $\begin{array}{l}\text { Community } \\
\text { decision } \\
\text { making }\end{array}$ & $\begin{array}{l}\text { The women } \\
\text { joined civil } \\
\text { associations and } \\
\text { opposed the } \\
\text { implementation } \\
\text { of the } \\
\text { "Cuetzalan } \\
\text { High Voltage } \\
\text { Line (LAT)" } \\
\text { project. } \\
\text { In addition, they } \\
\text { opposed the } \\
\text { construction of } \\
\text { a mine that } \\
\text { would use the } \\
\text { fracking } \\
\text { technique for } \\
\text { mineral } \\
\text { extraction. }\end{array}$ & $\begin{array}{l}\text { The artisans } \\
\text { supported the } \\
\text { operation of the } \\
\text { campaign for the } \\
\text { prevention of } \\
\text { breast cancer. } \\
\text { This campaign } \\
\text { was directed by } \\
\text { the Ministry of } \\
\text { Health. In } \\
\text { addition, they } \\
\text { give courses to } \\
\text { children to } \\
\text { separate solid } \\
\text { waste, they also } \\
\text { do traditional } \\
\text { herbal courses to } \\
\text { the public. In } \\
\text { addition, they } \\
\text { participated in } \\
\text { the construction } \\
\text { of a traditional } \\
\text { herbalist center. }\end{array}$ & $\begin{array}{l}\text { The woman } \\
\text { who started the } \\
\text { company and } \\
\text { legal } \\
\text { representative } \\
\text { is president of } \\
\text { the State } \\
\text { Association of } \\
\text { Pyrotechnics, } \\
\text { aims to design } \\
\text { rules that } \\
\text { regulate the } \\
\text { activity of } \\
\text { pyrotechnics in } \\
\text { the state of } \\
\text { Puebla. }\end{array}$ & $\begin{array}{l}\text { The peasants } \\
\text { have carried out } \\
\text { some short-term } \\
\text { and temporary } \\
\text { actions, for } \\
\text { example, they } \\
\text { collected and } \\
\text { separated } \\
\text { organic waste } \\
\text { and then made } \\
\text { compost. }\end{array}$ \\
\hline Learning & $\begin{array}{l}\text { The hotel } \\
\text { differs because } \\
\text { it is managed by } \\
\text { indigenous } \\
\text { women who are } \\
\text { dressed in } \\
\text { traditional } \\
\text { costumes. They } \\
\text { implemented } \\
\text { relaxing, } \\
\text { temazcal and } \\
\text { clean healing } \\
\text { massage }\end{array}$ & $\begin{array}{l}\text { They designed } \\
\text { and } \\
\text { implemented a } \\
\text { product line } \\
\text { called } \\
\text { innovators. The } \\
\text { purpose was to } \\
\text { manage } \\
\text { innovation to } \\
\text { satisfy its } \\
\text { customers. In } \\
\text { addition, they } \\
\text { made an alliance }\end{array}$ & $\begin{array}{l}\text { The } \\
\text { businesswomen } \\
\text { bought a } \\
\text { cutting-edge } \\
\text { technology } \\
\text { equipment for } \\
\text { the detonation } \\
\text { of pyromusical } \\
\text { games. This } \\
\text { team is totally } \\
\text { effective and } \\
\text { safe and they } \\
\text { are the only }\end{array}$ & $\begin{array}{l}\text { The peasants } \\
\text { learned to sow } \\
\text { with the } \\
\text { techniques they } \\
\text { showed them in } \\
\text { the training } \\
\text { courses. In } \\
\text { addition, they } \\
\text { innovated a } \\
\text { technique of } \\
\text { planting carrots, } \\
\text { introducing the } \\
\text { seeds in bottles }\end{array}$ \\
\hline
\end{tabular}




\begin{tabular}{|c|c|c|c|c|}
\hline & $\begin{array}{l}\text { services, also } \\
\text { carried out the } \\
\text { workshop to } \\
\text { learn the waist } \\
\text { loom, } \\
\text { implemented } \\
\text { the herbalist and } \\
\text { the store in } \\
\text { which they sell } \\
\text { handicrafts, } \\
\text { such as: clothes } \\
\text { that have } \\
\text { embroidery, } \\
\text { whose design } \\
\text { has been } \\
\text { gradually } \\
\text { adapted to the } \\
\text { taste of } \\
\text { customers. They } \\
\text { also have the } \\
\text { services of } \\
\text { guided tours } \\
\text { and community } \\
\text { tourism. }\end{array}$ & $\begin{array}{l}\text { with a producer } \\
\text { of huaraches to } \\
\text { sew on these } \\
\text { ocoxal crafts } \\
\text { and an alliance } \\
\text { with a fashion } \\
\text { designer from } \\
\text { the state of } \\
\text { Guanajuato, } \\
\text { México to } \\
\text { manufacture } \\
\text { ocoxal buttons } \\
\text { and sew them to } \\
\text { the sack that the } \\
\text { designer } \\
\text { manufactured. }\end{array}$ & $\begin{array}{l}\text { ones that have } \\
\text { it in their } \\
\text { community. }\end{array}$ & $\begin{array}{l}\text { of P.E.T. The } \\
\text { results were } \\
\text { carrots longer } \\
\text { than the carrots } \\
\text { that were planted } \\
\text { with the } \\
\text { technique they } \\
\text { learned. }\end{array}$ \\
\hline Sustainability & $\begin{array}{l}\text { They wash the } \\
\text { hotel bedding } \\
\text { with } \\
\text { biodegradable } \\
\text { soaps, separate } \\
\text { solid waste, use } \\
\text { oil traps, } \\
\text { privilege the use } \\
\text { of wood and } \\
\text { non-gas stoves, } \\
\text { as well as the } \\
\text { use of septic } \\
\text { tanks. }\end{array}$ & $\begin{array}{l}\text { They make a } \\
\text { responsible } \\
\text { collection of the } \\
\text { ocoxal that is on } \\
\text { the forest floor, } \\
\text { collecting only } 3 \\
\text { kilos for each } \\
\text { person when } \\
\text { they climb, an } \\
\text { action that } \\
\text { earned them the } \\
\text { appointment of } \\
\text { guardians of the } \\
\text { Iztaccíhuatl- } \\
\text { Popocatépetl } \\
\text { Park on behalf } \\
\text { of the } \\
\text { PROFEPA } \\
\text { (Federal Office } \\
\text { of }\end{array}$ & $\begin{array}{l}\text { The company } \\
\text { has designed } \\
\text { and } \\
\text { implemented } \\
\text { an efficient } \\
\text { safety and } \\
\text { accident } \\
\text { prevention } \\
\text { system, within } \\
\text { its company } \\
\text { and in public } \\
\text { shows, and is } \\
\text { also interested } \\
\text { in legislation so } \\
\text { that other } \\
\text { pyrotechnics } \\
\text { do not suffer an } \\
\text { accident. }\end{array}$ & $\begin{array}{l}\text { The peasants } \\
\text { learned organic } \\
\text { and sustainable } \\
\text { agriculture. }\end{array}$ \\
\hline
\end{tabular}




\begin{tabular}{|l|l|l|l|l|}
\hline & $\begin{array}{l}\text { Environmental } \\
\text { Protection). }\end{array}$ & & \\
\hline Culture & $\begin{array}{l}\text { Traditional } \\
\text { Machismo, even } \\
\text { the other } \\
\text { women of the } \\
\text { community } \\
\text { gave them the } \\
\text { nickname of } \\
\text { "the street" that } \\
\text { is, the women } \\
\text { who are not } \\
\text { only at home } \\
\text { doing } \\
\text { housework. }\end{array}$ & $\begin{array}{l}\text { Machismo, } \\
\text { buich extends to } \\
\text { activities, since } \\
\text { it is recognized } \\
\text { as the only } \\
\text { business activity } \\
\text { to the artisans of } \\
\text { the huarache. }\end{array}$ & $\begin{array}{l}\text { Machismo, the } \\
\text { activity of } \\
\text { pyrotechnics } \\
\text { was reserved } \\
\text { for men, before } \\
\text { this company } \\
\text { there were no } \\
\text { women in } \\
\text { charge and } \\
\text { there were no } \\
\text { owners of } \\
\text { pyrotechnics. }\end{array}$ & $\begin{array}{l}\text { Machismo, the } \\
\text { men are peasants } \\
\text { and bricklayers, } \\
\text { however, they } \\
\text { allowed women } \\
\text { to plant } \\
\text { vegetables in } \\
\text { their backyard. }\end{array}$ \\
\hline
\end{tabular}

Source: self-made.

The entrepreneurship investigated agreed on the lack of administrative training for women entrepreneurs, for example, to determine costs, set prices, account for the entry and exit of goods, advertise and market their products, among others. Regarding the technical skill to produce the products, there were some variations, the hotel Taselotzin artisans recovered traditional knowledge, that is, the waist fabric, the herbalist and the temazcal, on the other hand, the Artemali entrepreneurs lacked the technical expertise to elaborate Ocoxal handicrafts, in the case of El PIRA Hermanos company, to make thunder beads, the peasants did not know how to plant vegetables in their backyard.

The 4 enterprises have resorted to training, either to improve their administrative knowledge, such as marketing and advertising, or technicians, for example, to improve the artisanal technique of the ocoxal fabric, in the Artemali company, to improve the shows pyrotechnics in the company The PIRA Hermanos company and to plant vegetables in the backyard. In addition, the Taselotzin, Artemali companies and community of Samaria agreed to train their female members on the issue of women's empowerment and self-esteem improvement. In addition, women in community of Samaria received training in women's sexual and reproductive health rights.

The institutions that provided the training to the companies Taselotzin and Artemali were part of the government and others were public and private universities, instead the training received by the members of The PIRA Hermanos company was provided by private companies and by the Benemérita Autonomous University of Puebla. Samaria women farmers received training from an NGO, whose name cannot be disseminated because a confidentiality agreement was made.

Learning and innovation were common practices in all three enterprises, manifesting in significant changes in the goods and services that were marketed to meet the needs of customers. It follows that women entrepreneurs moved several times from training to organizational learning and from this to innovation, generating products and practices that allowed them to be more competitive in the market. Deepening in this virtuous fingerboard of 
training, organizational learning and innovation, it was observed that behind the successes, the entrepreneurs made several trials that served to build their own knowledge or know-how, which increases the organizational capacity to better use resources with which the organization has.

Sustainability is a characteristic of social enterprises and, it was observed in the three companies and in entrepreneurship in community of Samaria, in different practices and degrees. The Taselotzin hotel has sustainable practices related to nature care, which harmonize with the worldview of these Nahua women. In Artemali, something similar happens, sustainable actions are more evident in the care of the forest in collecting their raw material that is the ocoxal, therefore, it can be deduced that both companies strive for their ecological footprint is not very noticeable.

In the same order of ideas, the company PIRA Hermanos company is also sustainable because it strives to reduce and eliminate accidents caused by pyrotechnic shows that have historically caused many deaths in Mexico. On the other hand, the women of the community of Samaria practice organic and sustainable agriculture in the orchards that are in the backyard of their houses. Harvested foods consume them with certainty that they do not have fertilizers or pesticides that can harm their health.

In the same vein, the three enterprises have contributed to the care and improvement of their community, which is also characteristic of social enterprises. Artemali artisans, have generated positive impacts of various kinds, were promoters of the campaign to prevent breast cancer, taught courses on waste separation and herbalism. Taselotzin's entrepreneurial actions are more oriented towards the care of ecology, opposing collectively with other groups, the construction of the mine and the Cuetzalan High Voltage Line.

In the same vein, the woman who created El PIRA Hermanos company directs the state association of pyrotechnics and promotes the creation of norms to prevent accidents occurring within companies that engage in pyrotechnics and outside them, when they carry out their pyrotechnic and pyromusical shows. Regarding the community of Samaria, the women farmers have dedicated themselves to the collection and separation of organic waste and composting, which are sustainability actions related to the care of nature.

With respect to culture, in the rural communities in which the 3 companies operate, and in the community of Samaria, there is an exacerbated machismo, which also manifests itself in business activity. However, in the city of San Miguel Zacaola, the PIRA Hermanos company fractured the patriarchal hegemony of pyrotechnics to the extent that the state leader is a woman, in the city of Tepatlaxco de Hidalgo, the predominant activity is the manufacture of huaraches and is patriarchal, but Artemali with the Ocoxal handicraft manufacturing is positioned as the other important business activity.

Meanwhile, in the city of Cuetzalan, tourism is the emerging activity that contributes significantly to the local economy, Taselotzin hotel businesswomen through the collective organization of Nahua women contribute to the local economy and to the improvement of the conditions of their families In the same way, the peasants of the community of Samaria have agreed with their male partners, the planting and harvesting of vegetables in the backyard of their houses. 


\section{Conclusion}

Social entrepreneurship contributes to the empowerment of rural women, because it evidently allows them to dispose of the economic resources that they generate through their productive activity and thus, fracture cultural barriers such as the machismo of the community, which extends to paid productive activities. Although, if our vision has more scope, we can deduce that the collective action of women also promotes respect for their time and space, the care of their body and the disruption of gender roles, jealously controlled not only by men , if not for women who reproduce the tradition and who have opposed the same force or more than men.

The process of empowering women through entrepreneurship has nuances, accidents, fractures, setbacks and collateral damage, typical of the economic, social and cultural changes that occur in Mexico, because it disrupts economic interests and diminishes the power of many social actors who They strive to maintain the status quo, however, empowerment is an advancing trend and to which, it is necessary to contribute proactively, seeking alliances and not confrontations.

Entrepreneurship in the community of Samaria, as well as the Taselotzin, Artemali and El PIRA Hermanos companies, are some cases of social entrepreneurship and empowerment of rural women in Mexico. The challenge of researchers who want to contribute to improving the local, state and national economy will be to design models to generate social enterprises that contribute to creating a more sustainable and harmonious economy with the environment. To achieve the above, a network of researchers is needed that produces more evidence and collaborates with the government, international institutions and NGO's to finance them, in addition to creating incentives and tax regulation different from other types of companies..

\section{References}

Alonso, D. González, N., Nieto, M., 2015. Emprendimiento social vs innovación social. Cuadernos Aragoneses de Economía, Vol. 24, No. 1-2, pp. 119-140. Dirección de internet: http://www.gestionypoliticapublica.cide.edu/num_anteriores.

Bard, G., 2017. Pensamiento feminista latinoamericano" Revista Scielo (en línea), Vol. 11, No. 22, consultada el 1 de agosto de 2019. Dirección de internet: file://C:/Users/hvill/Documents/feminismo\%20América\%20Latina-Bard.pdf.

Córdova, R., 2013. Acceso de las mujeres a la tierra y patrones de herencia en tres comunidades ejidales del centro de Veracruz. Relaciones. Estudios de Historia y Sociedad, Vol. XXIV, No. 93.

Deere, C. y León, M., 2000. Género, propiedad y empoderamiento: tierra, Estado y mercado en América Latina, Bogotá, Colombia: Tercer mundo Editores en coedición con el Programa de Estudios de Género, Mujer y Desarrollo, Facultad de Ciencias Humanas, Universidad Nacional de Colombia.

Duarte, T., Ruiz Tibana, M., 2009. Emprendimiento, Una opción para el desarrollo" Revista Scientia Et Technica, Vol. XV, No. 43, pp. 326-331.

Kliksberg, B., 2011. Emprendedores sociales. Los que hacen la diferencia. Temas Grupo Editorial. 
Lastarria-Cornhiel, S., 2008. Feminización de la agricultura en América Latina y África. Tendencias y fuerzas impulsoras, RIMISP, Centro Latinoamericano para el Desarrollo Rural, Santiago de Chile.

López, V., Rojas, O., 2017. Rezagos en el nivel de autonomía de las mujeres rurales mexicanas en la primera década del siglo XXI. Revista de Estudios demográficos y urbanos (en línea), Vol. 32, No. 2, pp. 315-354, consultada en internet el 7 de abril de 2018. Dirección de internet: https://dx.doi.org/10.24201/edu.v32i2.1644.

Melián, A., Campos, V., 2010. Emprendedurismo y economía social como mecanismos de inserción sociolaboral en tiempos de crisis. REVESCO. Revista de Estudios Cooperativos, Norteamérica (en línea), Vol. 100. Consultado el 20 de marzo de 2018. Dirección de internet: http://revistas.ucm.es/index.php/REVE/article/view/19552.

Palacios, G., 2010. Emprendimiento social: integrando a los excluidos en el ámbito rural. Revista Scielo, Vol. 4, No. 16. Consultado el 24 de marzo de 2018. Dirección de internet: http://www.scielo.org.ve/scielo.php?script=sci_arttext\&pid=S131595182020000400002.

Rodríguez, A. y Flores, E., 2016. Análisis comparativo entre empresas de emprendimiento social vs empresas tradicionales por medio de indicadores financieros clave. Revista Vinculatégica, No. 1, pp. 2311-2338.

Vázquez, D., Mortera, D., Rodríguez, N., Martínez, M., Velázquez, M.G., 2013. Organización comunitaria de mujeres: del empoderamiento al éxito del desarrollo rural sustentable. Revista de Estudios de Género, la ventana (en linea) VoI. 5, consultada el 30 de marzo de 2018. Dirección de internet: http://www.redalyc.org/articulo.oa?id=88428978011. 